\title{
The Effect of Recombinant Human Erythropoietin on Bacterial Growth: A Dual-Edged Sword
}

\author{
Ankur Mittal $^{\mathrm{a}}$ Vandana Singh $^{\mathrm{a}}$ Sheemona Chowdhary ${ }^{\mathrm{a}}$ Amal Moideen $^{\mathrm{b}}$ \\ Deepak Kumar $^{\text {a }}$ Kunal Maniar $^{\mathrm{b}}$ Rajasri Bhattacharyya ${ }^{\mathrm{a}}$ Dibyajyoti Banerjee $^{\mathrm{a}}$ \\ aDepartment of Experimental Medicine and Biotechnology, Postgraduate Institute of Medical Education and \\ Research, Chandigarh, India; ${ }^{b}$ Department of Pharmacology, Postgraduate Institute of Medical Education and \\ Research, Chandigarh, India
}

\section{Keywords}

Anaemia - Bacteria $\cdot$ Chronic renal disease $\cdot$ Cytokines $\cdot$

Erythropoietin $\cdot$ Infection

\begin{abstract}
Background: Hypererythropoietinemia is associated with common diseases like non-uremic anaemia where infection burden is high. Erythropoietin (EPO) is also given as therapy for anaemia associated with chronic kidney disease and cancer and in those who are at a higher risk of infections. EPO is known to have an effect on macrophages by which it helps in the growth of some intracellular pathogens. However, its direct role on bacterial growth is currently unknown. Summary: Here, we investigated the direct effect of recombinant human erythropoietin (rhuEPO) on the growth of pathogenic Escherichia coli, Staphylococcus aureus and Pseudomonas aeruginosa. In silico experiments were designed to gain insight into the mechanisms. We found that $30 \mathrm{IU} / \mathrm{L}$ rhuEPO promoted the growth of E. coli and S. aureus and inhibited the growth of $P$. aeruginosa. In silico observations suggest that bacterial cell surface proteins may interact with the EPO
\end{abstract}

\section{KARGER}

(c) 2018 S. Karger AG, Basel

E-Mail karger@karger.com

www.karger.com/kdd and may cause the observed effects. Key Message: It appears that some pathogens can explore EPO to proliferate and growth of others are inhibited by the same. The consequence of such observation is a matter of widespread concern for future research.

C) 2018 S. Karger AG, Basel

\section{Introduction}

Erythropoietin (EPO) is the primary glycoprotein cytokine responsible for the growth and differentiation of red blood cells in humans [1]. It is predominantly produced in the kidney (in adults) and shares a negative correlation with the oxygen concentration in the body. Recombinant human erythropoietin (rhuEPO) is given as an adjunct for the therapy of anaemia in individuals affected by many conditions such as chronic kidney disease [2]. In patients with non-uremic anaemia, the EPO levels are several hundred-fold higher [3] (physiological range: 3-18 IU/L [4]). Although rhuEPO administration reduces the number of transfusions in critically ill settings and 
patients with sepsis, its effect on bacterial growth is unknown. Patients with infectious diseases and concomitant anaemia have a much poorer outcome than their non-anaemic counterparts (see discussion).

Further, it is observed that the EPO levels of non-survivors are significantly higher than the corresponding levels in survivors in critically ill patients [5]. High-dose rhuEPO administration was associated with more harm in patients admitted to critical care due to medical (nontrauma) reasons [6]. Cytokines such as interleukin beta, interleukin-6, and tumour necrosis factor alpha modulate the growth of the bacteria directly and indirectly [7]. There is already some evidence to suggest that EPO increases the intracellular Salmonella spp. load, and EPO administration in vivo is associated with reduced survival and impaired clearance of bacteria [8], showing an indirect role of EPO on bacterial growth. The direct effect of EPO on the growth of bacteria is not known. Here we investigated the effect of rhuEPO, on itself and on the growth of some bacteria.

\section{Materials and Methods}

\section{Computational Analysis}

Using the Biogrid 3.4 networking tools, we identified proteins that interact with EPO (see online suppl. Fig. 2; for all online suppl. material, see www.karger.com/doi/10.1159/000493684). EPO interacts with EPOR (quantitative score: 0.97) and GINM1 (Glycoprotein integral membrane 1; quantitative score: 0.79) [9]. In UniProt, using the search term "glycoprotein integral membrane protein in e coli," 4 proteins were identified, one of which was adhesin (uniport id: Q47692). The EPO-binding region of EPOR is reported between residues 1 and 225, and that EPO binds with preformed EPOR dimer. In RCSB protein databank, PDB code: $2 \mathrm{jkj}$ is a complex of Escherichia coli adhesin with chloramphenicol succinate. We aligned the sequence of EPO binding region of human EPOR (UniProt id: P19235) with E. coli adhesin membrane protein (PDB code: 2jkj) using CLUSTALW online tools to check the similarity (see online suppl. Fig. 1). We then docked EPO (taken from PDB code: 1eer) with $E$. coli adhesin protein (taken from PDB code: $2 \mathrm{jkj}$ ), and EPO with EPOR monomer (PDB code: 1eer) using the Rosetta Docking protocol [10]. Although X-ray structure of EPO-EPOR dimer complex is available to validate the docking method, we also docked EPO with EPOR dimer using Rosetta Docking protocol (see online suppl. Fig. 3 and 4). Molecular dynamics simulation was performed by the established procedure to understand the stability of the test complex $[11,12]$. Structures were visualised using PyMOL.

\section{Bacterial Strains}

E. coli 9492 (Pathogenic; isolated initially from human vaginal swab), Staphylococcus aureus 3160 (pathogenic; originally isolated from carbuncle), and Pseudomonas aeruginosa 3542 (Pathogenic; originally isolated from human) were obtained from Microbial Type Culture Collection and Gene Bank, Chandigarh, India.

\section{Drugs and Media}

Nutrient agar and broth for the growth of bacteria were obtained from Hi-Media Laboratories, India. rhuEPO (EPOFIT PFS $2000 \mathrm{IU} / \mathrm{mL}$; INTAS Pharmaceuticals, India) contains citric acid (0.06 mg), sodium citrate $(5.8 \mathrm{mg})$ and sodium chloride $(5.8 \mathrm{mg})$. Human serum albumin (HSA) is obtained from Sigma-Aldrich. $5 \mu \mathrm{L}$ of the EPOFIT is dissolved in $95 \mu \mathrm{L}$ sterile $0.9 \%$ saline. Appropriate control is prepared by dissolving Sodium citrate $(0.0058 \mathrm{~g})$, Sodium chloride $(0.0058 \mathrm{~g})$ and HSA $(0.0025 \mathrm{~g})$ in $940 \mu \mathrm{L}$ of sterile distilled water. Citric acid measuring $0.001 \mathrm{~g}$ is dissolved in $1 \mathrm{~mL}$ sterile distilled water, and from it, $60 \mu \mathrm{L}$ is added to the $940 \mu \mathrm{L}$ solution of HSA containing $\mathrm{NaCl}$ and sodium citrate. Phosphate buffer solution (PBS) is prepared by dissolving Potassium Phosphate Monobasic (0.010 g), di-Sodium Hydrogen Phosphate anhydrous $(0.07 \mathrm{~g})$, Potassium Chloride (0.10 g) and Sodium chloride (0.4 g) in $50 \mathrm{~mL}$ sterile distilled water. Alamar blue (AB; HiMedia Labs TC2351G) is prepared by dissolving $0.005 \mathrm{~g} \mathrm{AB}$ in $5 \mathrm{~mL} \mathrm{PBS}$, and $1 \mathrm{~mL}$ from it $(\mathrm{AB}+\mathrm{PBS})$ is dissolved in sterile $50 \mathrm{~mL}$ nutrient broth.

\section{Bacterial Colony Count}

A pure bacterial culture is obtained, and a teasing inoculation is dissolved in $15 \mathrm{~mL}$ of sterile Nutrient broth. Bacterial $0.5 \mathrm{McFar}-$ land $(\mathrm{McF})$ is prepared and compared to standard (Hi-Media Labs R092-1NO). It is divided equally into 3 sterile tubes $(5 \mathrm{~mL}$ each; labelled as test [T], control [C] and blank [B]) and $1.5 \mu \mathrm{L}$ of rhuEPO (corresponding to $30 \mathrm{IU} / \mathrm{L}$ ) and $1.5 \mu \mathrm{L}$ of stock control are added in 2 tubes. The remaining tube containing bacterial $0.5 \mathrm{McF}$ is marked as a blank (B). All tubes are incubated at $37^{\circ} \mathrm{C}$ for $2 \mathrm{~h}$, and each sample was serially diluted by adding $100 \mu \mathrm{L}$ of bacterial suspension to $900 \mu \mathrm{L}$ of sterile nutrient broth. The appropriate dilutions were prepared, and $20 \mu \mathrm{L}$ of the broth suspension was used for spreading and plating. The plates were incubated overnight at $37^{\circ} \mathrm{C}$ in the incubator, and colony counts were performed.

\section{Alamar Blue Assay}

Bacterial $0.5 \mathrm{McF}$ is prepared (as described previously) and compared to standard. Test, control and blank tubes are prepared, as described previously, and incubated for $2 \mathrm{~h}$ at $37^{\circ} \mathrm{C}$. Each sample was serially diluted by adding $100 \mu \mathrm{L}$ of bacterial suspension to $900 \mu \mathrm{L}$ of sterile Nutrient broth (containing AB). The microfuge tubes are then incubated at $37^{\circ} \mathrm{C}$ and observed hourly for the colour formation. This assay uses Alamar Blue (resazurin; a redox indicator), which in its oxidised state remains dark blue [13]. Bacterial growth induces the reduction of the indicator, which then turns pink.

\section{Growth Curve Analysis}

Bacterial 0.5 McF is prepared (as described previously) and compared to standard. Test, control and blank tubes are prepared, as described previously, and incubated for $2 \mathrm{~h}$ at $37^{\circ} \mathrm{C}$. Appropriate dilutions of each sample are prepared by taking $100 \mu \mathrm{L}$ of bacterial suspension to $900 \mu \mathrm{L}$ of sterile nutrient broth. Appropriate dilution to the extent of $200 \mu \mathrm{L}$ is added to 96 well ELISA plate (NST biotech) and incubated in a multimode reader (TECAN M $\mathrm{PRO} 200)$ at $37^{\circ} \mathrm{C}$ under linear shaking condition at an interval of $1,000 \mathrm{~s}$ for 45 cycles at an amplitude of 1.5. The absorbance is taken at $520 \mathrm{~nm}$ at the end of each cycle. Absorbance versus time is plotted up to $12.5 \mathrm{~h}$. Growth curve analysis was also performed by adding the $10^{-2}$ dilutions of bacteria to a nutrient broth containing $10 \%$ serum. The dilutions were not incubated for $2 \mathrm{~h}$ for this ex- 

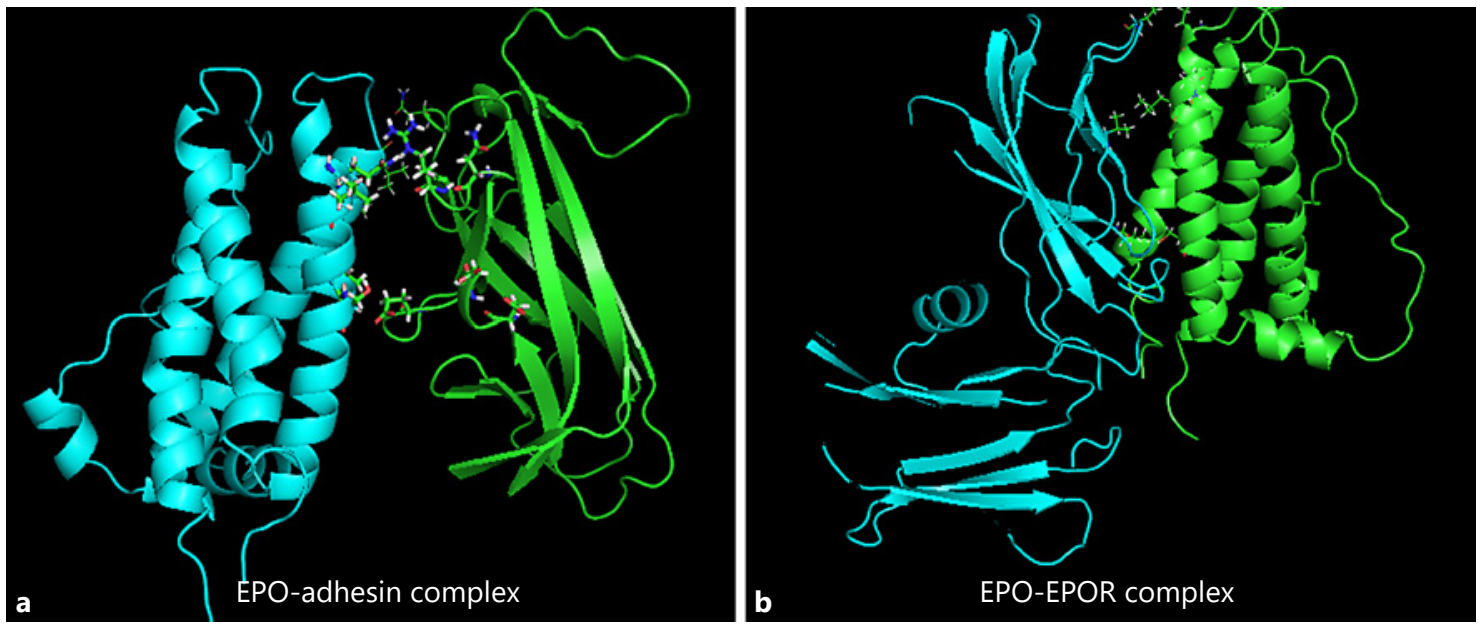

Fig. 1. a The docked structure of erythropoietin (EPO; blue) with E. coli adhesin (green) protein (residues not labelled; for details, please see text). b The docked structure of EPO (green) with EPOR (residues not labelled; for details, please see text).

periment. Serum was prepared by keeping fresh blood in sterile autoclaved containers for half an hour and then the blood was centrifuged at 3,000 rpm for $3 \mathrm{~min}$.

\section{Bacterial Membrane Isolation and Quenching with EPO}

To analyse the interaction between bacterial membrane proteins and EPO, quenching of the native fluorescence of membrane protein was studied in the presence of EPO. Cell culture-tested lyophilised powder of rhuEPO expressed in $\mathrm{CHO}$ cells containing $\sim 100,000$ units of the hormone per mg of protein was purchased from Sigma (Catalogue No: E5627-10UN, Lot No \#SLBK6398V, Code: 10001830974). It was diluted to a desired concentration in the course of the study using phosphate buffer saline $(0.1 \mathrm{M}$, with a pH 7.38 measured using Elico pH meter). E. coli bacterial membrane was isolated as previously described [14]. The concentration of membrane protein in the sample is estimated by studying its absorbance at $280 \mathrm{~nm}$ using Elico (SL 244) double beam spectrophotometer. Phosphate buffer is used for dissolving the membrane protein or for making the reaction mixture. Carry eclipse Fluorescence Spectrophotometer version 1.1 (132) with default settings was used for fluorescence measurements. The width of both excitation and emission slit were set at $5 \mathrm{~nm}$. PMT detector voltage: Medium (600).

The quenching in the native fluorescence of membrane protein was studied in the presence of different concentrations of EPO. The fluorescence emission spectra of the reaction mixtures in the range of $210-700 \mathrm{~nm}$ were studied at various excitation wavelengths $(\lambda \mathrm{Ex})$ ranging from 210 to $300 \mathrm{~nm}$. The stern-volmer equation is used for analysing the quenching data:

$$
\mathrm{F} 0 / \mathrm{F}=1+\mathrm{Ksv}(\mathrm{Q}) \text {. }
$$

where F0 and F are steady-state fluorescence intensities in the absence and presence of quencher respectively. Ksv is the SternVolmer quenching constant and (Q) is the concentration of the quencher (i.e., EPO). The modified Stern-Volmer equation is used for determining the number of binding sites $(n)$ :

$$
\log (\mathrm{F} 0-\mathrm{F} / \mathrm{F})=\log \mathrm{K}+\mathrm{n} \log (\mathrm{Q})
$$

\section{Statistical Analysis}

All values of colony count obtained are represented as mean \pm SDs. Unpaired Student $t$ test was used for comparing colony counts. A $p$ value of $<0.05$ is taken as significant.

\section{Results}

\section{Computational Analysis}

It was observed that the residues V82, Q92, L93 and V99 of EPO were in close approximation with residues E66, D61, R78, N76, and N122 of Adhesin protein of $E$. coli (Fig. 1a). In biological conditions, EPO binds with preformed EPOR dimer [15] and EPOR binding peptides (ERP) bind with membrane proximal residues of EPOR monomer (residues 174-223) [16]. Using EPOR monomer as a control, it was noted that the residues E89, Q92, L93 and S104 of EPO were closely approximated to residues E134, L175 and V182 of EPOR membrane-proximal region in the docked complex (Fig. 1b). We also docked EPO with EPOR dimer (result not shown), and interaction patterns resemble those that are observed in the crystal structure. The protein binding sites of adhesin has already been reported in the literature, and one of the binding pockets comprises D61, D63, D75, N77 and I172 (similar to the residues involved in EPO and adhesin in our study) [17]. The binding region of EPO is similar for both EPO-EPOR monomer and EPO-adhesin complexes, indicating that via docking, we can predict the binding of EPO with adhesin. The highest interface score for EPO-adhesin interaction obtained was -4.275 and the 


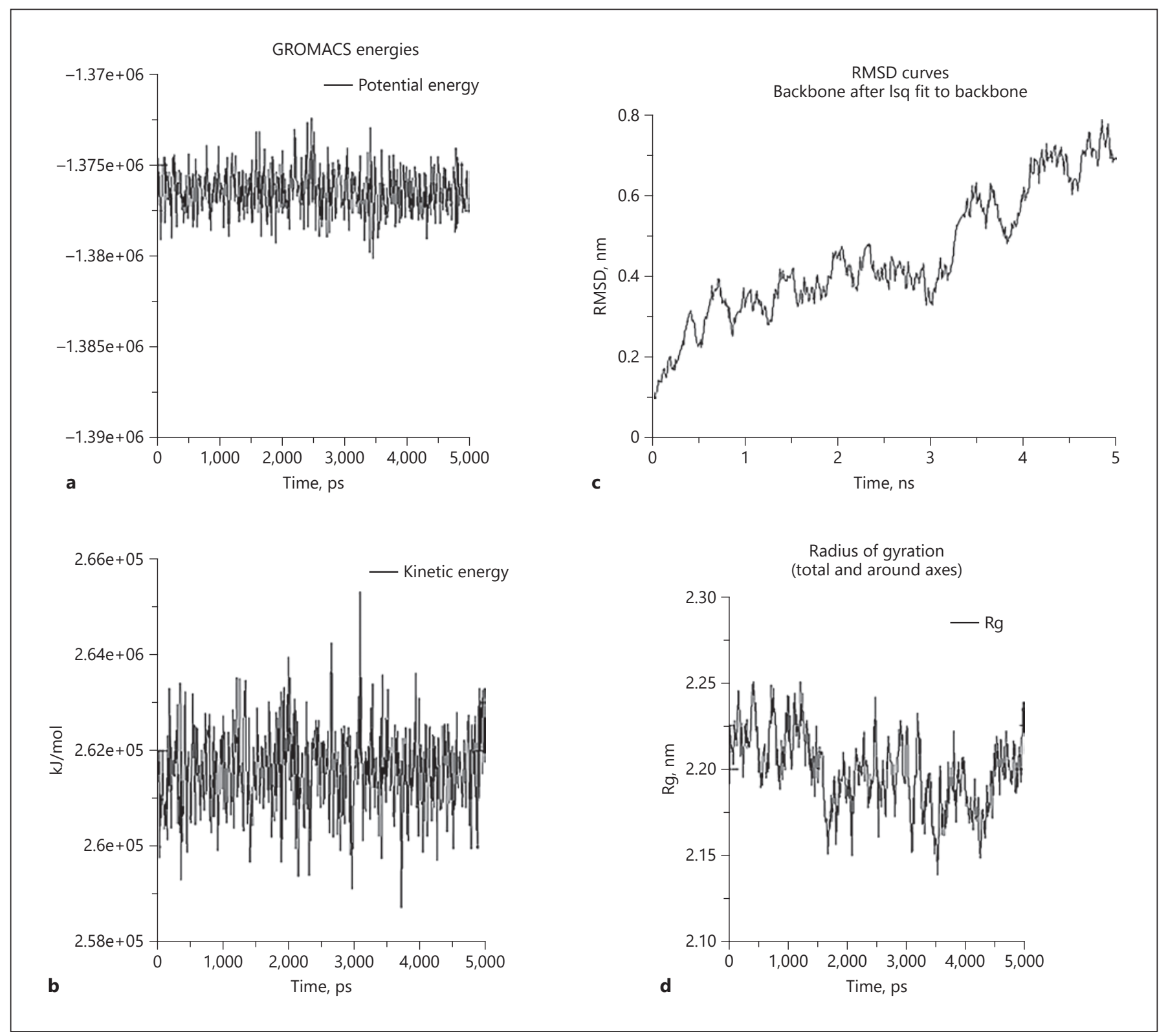

Fig. 2. Molecular dynamics simulations of EPO adhesion complex showing a Potential energy, b Kinetic energy, c RMSD (root mean square deviation) curves, d Radius of gyration (ps: picoseconds; ns: nanoseconds).

same for EPO-EPOR monomer interaction was -5.977 . To further validate this result, a molecular dynamics simulation was performed as previously described by our team $[11,12]$. After the simulation run, the complex was observed to be stable (see online suppl. Fig. 5). It was observed that after $5 \mathrm{~ns}$ run, the kinetic and potential energies as well as the radius of gyration were fluctuating against constant values (Fig. $2 \mathrm{a}-\mathrm{c}$ ). However, the RMSD curve is suggestive of high-dimensional data due to the formation of the protein-protein complex [18] (Fig. 2d). The complex after docking shows stability.

\section{Colony Counts}

The colony counts of $S$. aureus 3160 incubated in test plates $(269.83 \pm 65.12 ; n=6$, represented as mean \pm SD) were significantly more than those of controls (205.16 \pm $15.68 ; n=6 ; p<0.0001$; Fig. 3b). The colony counts of the pathogenic E. coli 9492 incubated with rhuEPO (50 \pm 


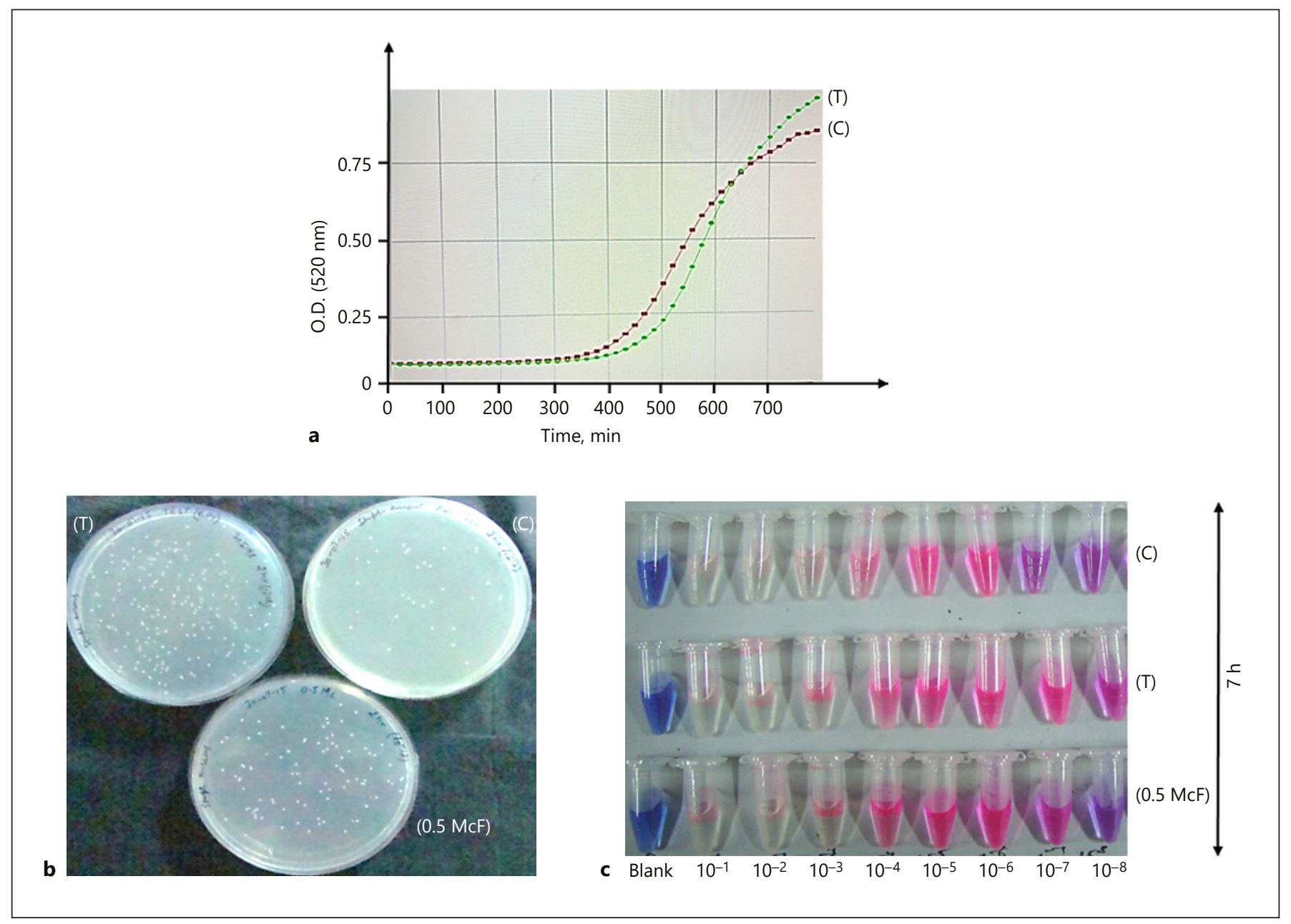

Fig. 3. a Growth curve of $S$. aureus. Bacteria were incubated with $30 \mathrm{IU} / \mathrm{L}$ of rhuEPO (T; shown in green) or appropriate control (C; shown in red). Absorbance (optical density [O.D.] at $520 \mathrm{~nm}$ ) was plotted every $1,000 \mathrm{~s}$ for $12.5 \mathrm{~h}$ (x-axis). After $600 \mathrm{~min}$, the growth of bacteria incubated with rhuEPO is more than control. b Representative picture of plates for colony count experiments of $S$. aureus. Bacteria were incubated with rhuEPO or control for $2 \mathrm{~h}$ after which they were plated. The colony counts of bacteria incubated with rhuEPO (T) were significantly higher than those of controls
(C); $p<0.05$ (see online suppl. data). c AB assay, showing microfuge tubes after $7 \mathrm{~h}$. Bacteria were incubated in the presence of rhuEPO or control for $2 \mathrm{~h}$; post which serial dilutions were performed using nutrient broth containing $\mathrm{AB}$. The microfuge tubes were observed hourly for colour change. The control tubes $(\mathrm{C})$ at $10^{-7}$ and $10^{-8}$ dilutions are bluish purple, whereas the corresponding test tubes $(\mathrm{T})$ are pink, indicating that rhuEPO promotes the growth of $S$. aureus. McF, McFarland.
$17.53 ; n=6$; represented as mean $\pm \mathrm{SD}$ ) were significantly higher than those of controls $(24 \pm 5.21 ; n=6$; $p=$ 0.0059; Fig. 4b). In the presence of rhuEPO, the colony counts of $P$. aeruginosa ranged between 54 and 89 and showed no pigmentation. The colony counts of the control group are more than 300 , and pigmentation is appreciable (Fig. 5b). A disc diffusion assay showed a zone of inhibition (Fig. 5c). The full data of colony count experiment is collated into a table, available as online Supplementary material.

EPO and Bacterial Growth
AB Assay

The pink colour (indicating growth), is observed up to $10^{-6}$ dilutions in the test and control groups of $S$. aureus 3160 at $7 \mathrm{~h}$ (Fig. $3 \mathrm{c}$ ). The $10^{-7}$ and $10^{-8}$ dilutions of the control group were bluish-purple, whereas the corresponding test microfuge was pink, thus indicating that the growth of bacteria in the presence of rhuEPO is more than controls. For E. coli 9492 , at 7 h, the control group shows a blue colour at $10^{-6}$ dilution, whereas the corresponding test group demonstrated pink colour (Fig. 4c). 

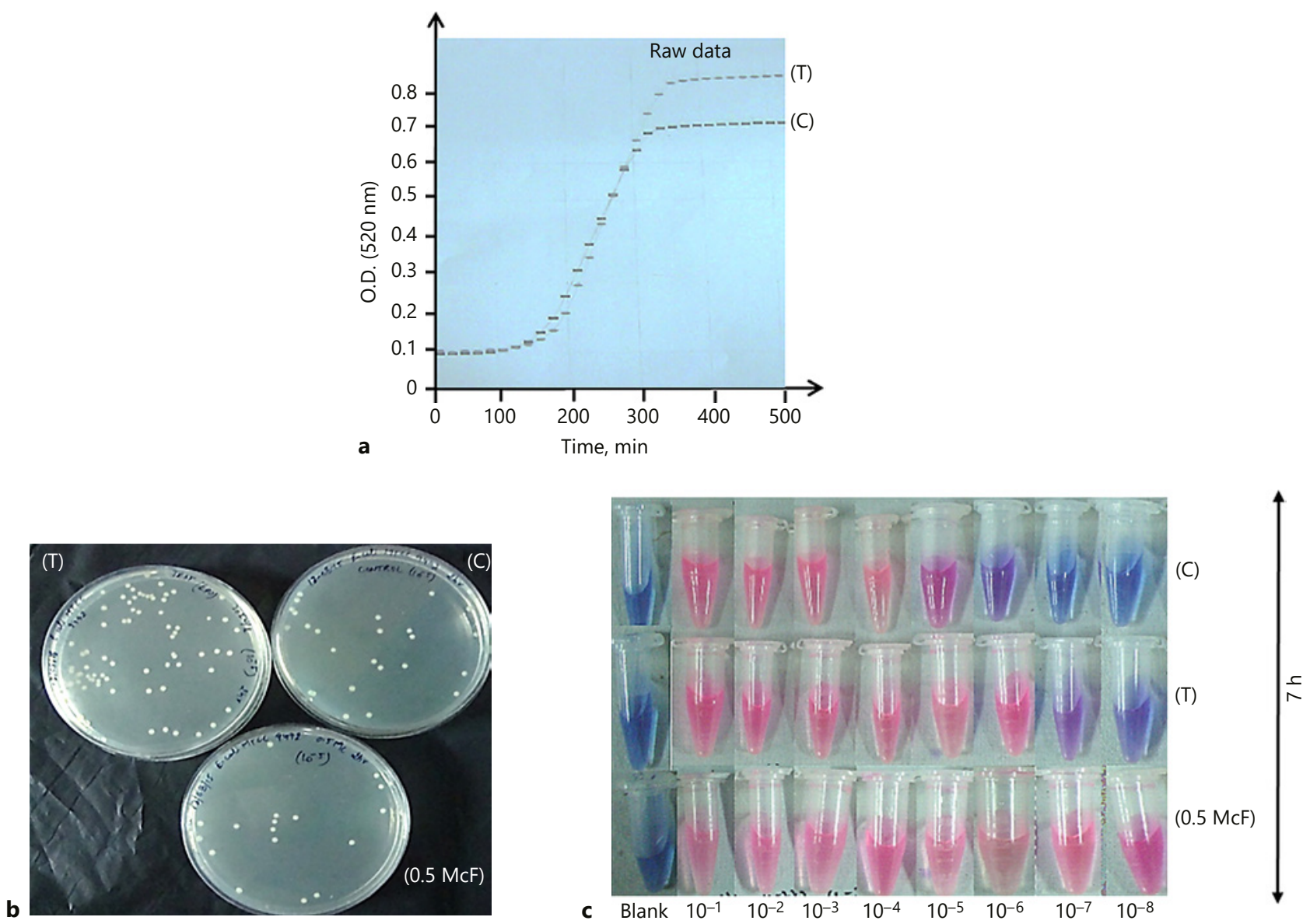

Fig. 4. a Growth curve of $E$. coli. Bacteria were incubated with 30 $\mathrm{IU} / \mathrm{L}$ of rhuEPO ( $\mathrm{T}$; shown in green) or appropriate control (C; shown in red). Absorbance (optical density [O.D.] at $520 \mathrm{~nm}$ ) was plotted every $1,000 \mathrm{~s}$ for $12.5 \mathrm{~h}$ (x-axis). After $300 \mathrm{~min}$, the growth of bacteria incubated with rhuEPO is more than control. b Representative picture of plates for colony count experiments of E. coli. Bacteria ere incubated with rhuEPO or control for $2 \mathrm{~h}$ after which they were plated. The colony counts of bacteria incubated with

The blue colour is observed in both the test and in control groups at $10^{-7}$ and $10^{-8}$ dilutions. At $12 \mathrm{~h}$, the $10^{-4}$ dilution of control microfuge was pink, but its analogous test was blue (Fig. 5d). From $10^{-5}$ dilution onwards, the control microfuge tubes were pinkish, while the comparable test microfuge tubes were blue, signifying that the tested dose of rhuEPO inhibits the growth of this bacteria.

\section{Growth Curve Analysis}

The optical density (O.D.) of test and control microfuge tubes containing $S$. aureus is the same till $300 \mathrm{~min}$
rhuEPO (T) were significantly higher than those of controls (C); $p<0.05$ (see online suppl. data). c AB assay, showing microfuge tubes after $7 \mathrm{~h}$. Bacteria were incubated in the presence of rhuEPO or control for $2 \mathrm{~h}$; post which serial dilutions were performed using nutrient broth containing $\mathrm{AB}$. The control tube $(\mathrm{C})$ at $10^{-7}$ dilution is blue, whereas the corresponding test tubes $(\mathrm{T})$ are purple, indicating that rhuEPO promotes the growth of E. coli. McF, McFarland.
(Fig. 3a). From 300 to $650 \mathrm{~min}$, the O.D. of control is more than test. After $650 \mathrm{~min}$, the O.D. of the test is more than that of the control. This shows that after $650 \mathrm{~min}$, the growth of bacteria incubated with rhuEPO is more than controls; further suggesting that rhuEPO promotes the growth of $S$. aureus. Repeating the experiment without the incubation period yielded similar results (see online suppl. Fig. 6a). The O.D. of test and control microfuge tubes containing E. coli is the same until $100 \mathrm{~min}$ (Fig. 4a). From 150 to $250 \mathrm{~min}$, the O.D. of control is more than that of the test. After $300 \mathrm{~min}$, the O.D. of the test is more 


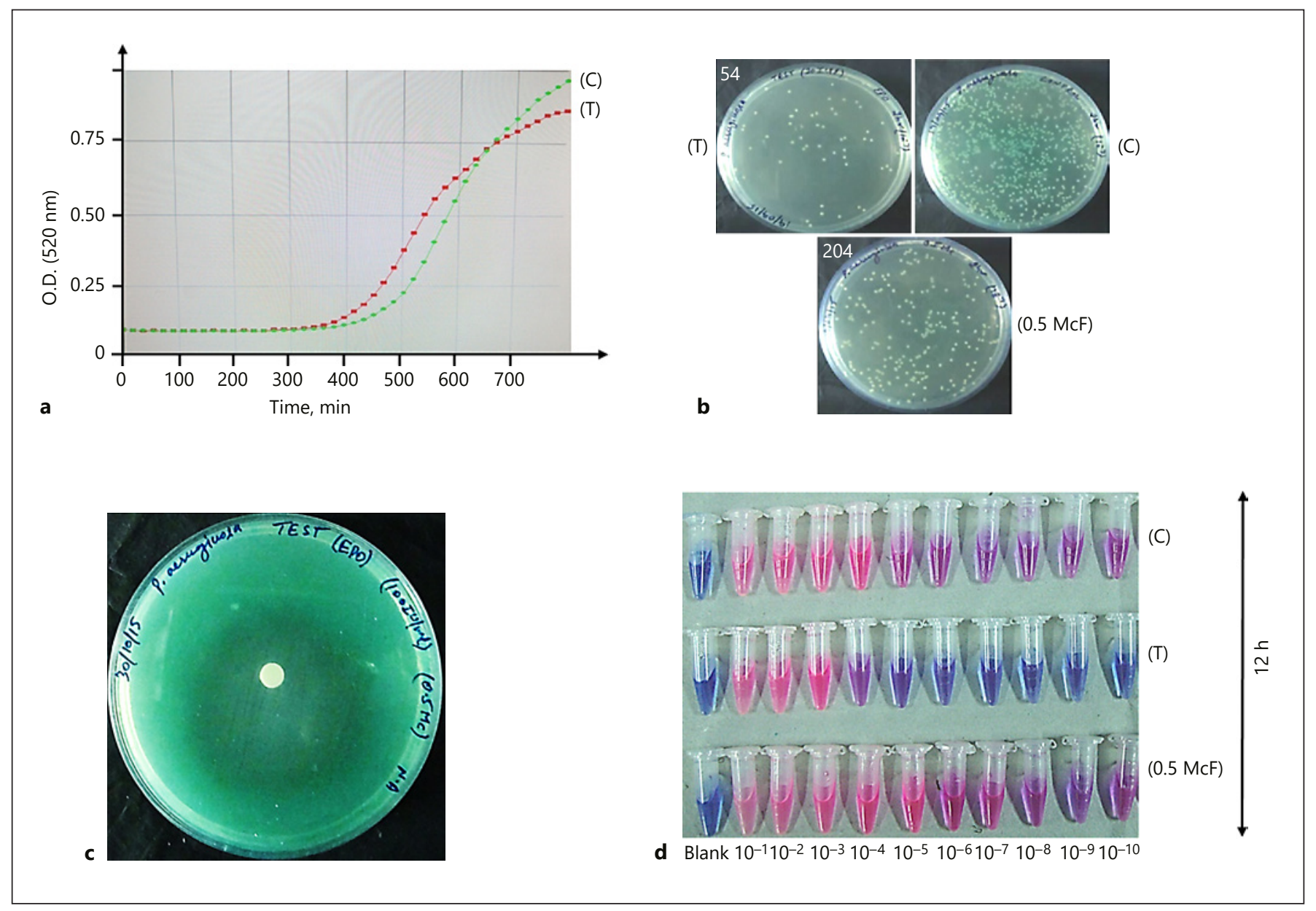

Fig. 5. a Growth curve of $P$. aeruginosa. Bacteria were incubated with $30 \mathrm{IU} / \mathrm{L}$ of rhuEPO ( $\mathrm{T}$; shown in red) or appropriate control (C; shown in green). Absorbance (optical density [O.D.] at $520 \mathrm{~nm}$; plotted on y-axis) was plotted every $1,000 \mathrm{~s}$ for $12.5 \mathrm{~h}$ (x-axis). After $600 \mathrm{~min}$, the growth of bacteria incubated with rhuEPO is less than control. b Representative picture of plates for colony count experiments of $P$. aeruginosa. Bacteria were incubated with rhuEPO or control for $2 \mathrm{~h}$ after which they were plated. The colony counts of bacteria incubated with rhuEPO (T) were significantly lower than controls (C); $p<0.05$ (see online suppl. Table). c Plate is showing the zone of inhibition of $P$. aeruginosa in the presence of rhuEPO. d AB assay, showing microfuge tubes after $12 \mathrm{~h}$. Bacteria were incubated in the presence of rhuEPO or control for $2 \mathrm{~h}$; a post which serial dilutions were performed using nutrient broth containing $\mathrm{AB}$. The control tubes (C) at $10^{-5}$ to $10^{-10}$ dilutions are pink, whereas the corresponding test tubes $(\mathrm{T})$ are blue, indicating that rhuEPO inhibits the growth of $P$. aeruginosa. McF, McFarland. than control. This shows that after $300 \mathrm{~min}$, the growth of bacteria incubated with rhuEPO is more than that of the controls; further suggesting that rhuEPO promotes the growth of E. coli. On repeating the experiment, without the 2-h incubation period, we found that the inhibitory effect of rhuEPO is lost (see online suppl. Fig. 6b). The O.D. of test and control microfuge tubes containing P. aeruginosa is the same until $300 \mathrm{~min}$ (Fig. 5a). From 300 to $600 \mathrm{~min}$, the O.D. of the test is more than that of the control. After $600 \mathrm{~min}$, the O.D. of control is more than that of the test. This shows that after $600 \mathrm{~min}$, the growth of bacteria incubated with rhuEPO is lesser than that in controls, further suggesting that rhuEPO inhibits the growth of $P$. aeruginosa. Moreover, on repetition without incubation period and in the presence of $10 \%$ serum, the inhibitory effect of rhuEPO on P. aeruginosa was retained (see online suppl. Fig. 6c, d).

\section{Bacterial Membrane Isolation and Quenching with EPO}

Through absorbance spectra at $280 \mathrm{~nm}$, we found that the concentration of membrane protein in the sample is 


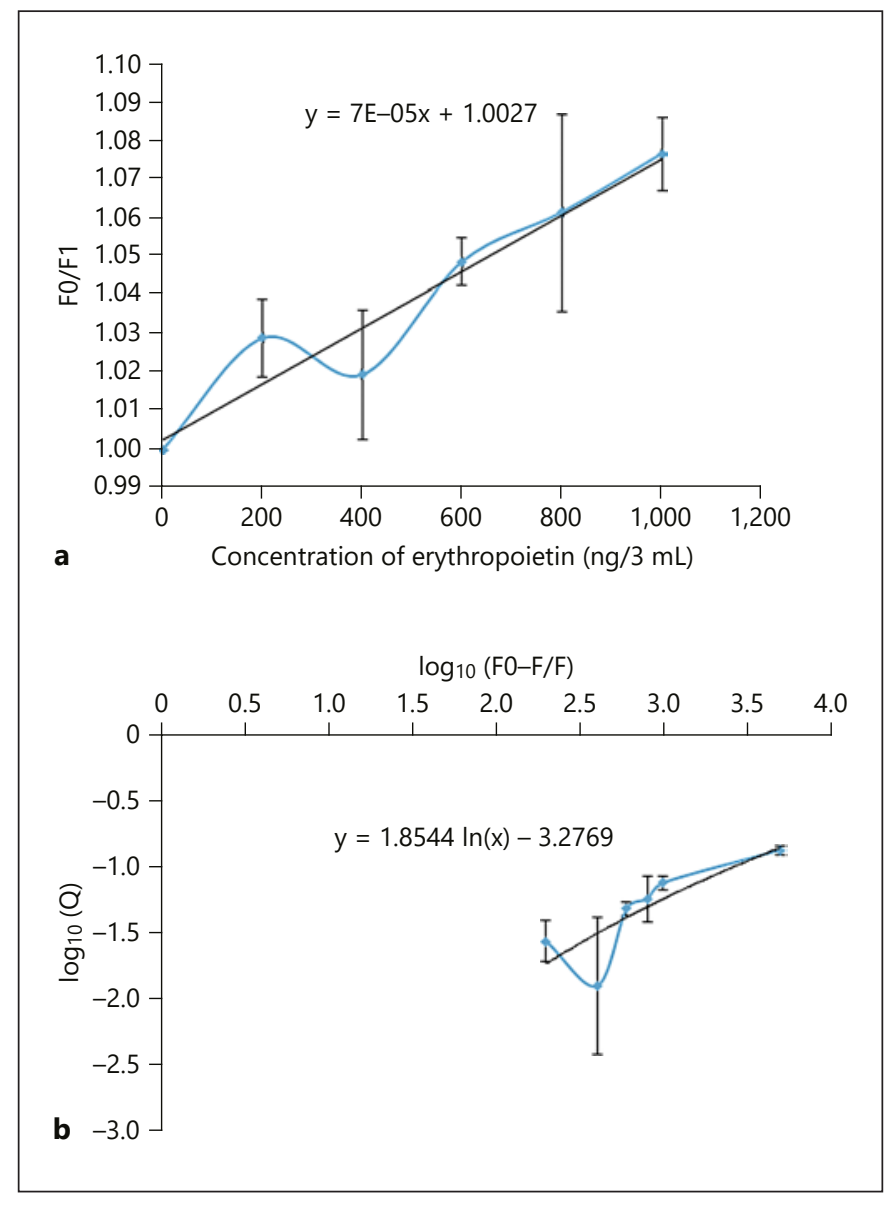

Fig. 6. a Stern-Volmer plot showing linear trend of interaction of membrane protein $(0.025 \mathrm{mg} / 3 \mathrm{~mL})$ with different concentration of EPO $(0,200,400, \ldots, 1,000 \mathrm{ng} / 3 \mathrm{~mL})$. b Modified Stern-Volmer plot of the interaction of membrane proteins $(0.025 \mathrm{mg} / 3 \mathrm{~mL})$ with different concentration of $\operatorname{EPO}(200,400, \ldots, 1,000$ and $5,000 \mathrm{ng} / 3 \mathrm{~mL})$.

around $1 \mathrm{mg} / \mathrm{mL}$ (see online suppl. Fig. 7). In fluorescence spectrophotometry study, we observed that after the addition of membrane protein $(0.025 \mathrm{mg} / 3 \mathrm{~mL})$, the fluorescence intensity of phosphate buffer increased maximum when excited at $240 \mathrm{~nm}$ (see online suppl. Fig. 8, 9). Therefore, the fluorescence emission for reaction mixture was recorded at $\lambda_{\mathrm{Ex} 240} / \lambda_{\mathrm{Em} 484}$ for studying the interaction. The obtained Stern-Volmer plot is shown in Figure 6a. The nature of the plot is linear. It clearly indicates that EPO quenches fluorescence emission of the bacterial proteins when excited at $240 \mathrm{~nm}$ in a dose-dependent manner. This phenomenon hints that EPO interacts with isolated bacterial membrane proteins. The modified Stern-Volmer equation is used for determining the number of binding sites (n) and is shown in Figure $6 \mathrm{~b}$.
The value of $\mathrm{n}$ is 1.8544 at $\lambda_{\mathrm{Ex} 240}$ representing more than one binding site in the membrane.

\section{Discussion}

Here, for the first time, we show that rhuEPO has a direct effect on bacterial growth. rhuEPO stimulated the growth of pathogenic E. coli and S. aureus, whereas inhibited the growth of $P$. aeruginosa. These effects were obtained at a concentration of $30 \mathrm{IU} / \mathrm{L}$, which is found in patients with mild anaemia [19]. A previous study by a different group indicated that EPO has an indirect pleiotropic effect on gram-negative infections mediated via the macrophages (in-vitro EPO concentrations used were $5 \mathrm{U} / \mathrm{mL}$ ) [8]. As has been comprehensively reviewed by the same group, the action of EPO on infectious diseases is context-dependent, and influenced by a variety of factors [20]. Here, we show that rhuEPO, in supraphysiological concentrations, can also have independent actions on bacteria. Unlike previous studies where cytokines have been implicated in causing the growth of bacteria [7], EPO can also act to inhibit the growth of bacteria. Our group has also proved that supra-physiological concentrations of insulin increase the growth of certain bacteria [21], thus giving further evidence that bacteria and host biomolecules interact to influence the pathogenesis of various diseases. Our work has several limitations. The mechanism by which EPO exerts its action on bacteria needs to be investigated thoroughly. We tested a single dose of rhuEPO in 3 strains only. A dosedependent study in different strains commonly affecting anaemic patients is required for further understanding host biomolecule - bacterial interactions, and to pursue the development of novel antibiotics. This being an invitro study, its interpretation cannot be extended to humans, though the current data on human trials seems to corroborate with our findings.

It is possible that the use of rhuEPO for therapy while being beneficial to patients may also make them vulnerable to develop infections. Further, higher EPO concentrations found in common diseases may also be predisposing the patients to certain type of infections, whereas conferring them may protect them against infections by other organisms. Infections are a common finding in anaemic patients.

Gram-negative infections were found to be more common in anaemic patients in trials, with a reported incidence of $33 \%$ of patients affected by pneumonia and having haemoglobin $<10 \mathrm{~g} / \mathrm{dL}$ [22]. Staphylococcal infec- 
tions were more common in patients with significantly reduced hematocrit [23], and high EPO concentrations were an independent predictor of mortality in diabetic patients (the patients with high endogenous EPO had concentrations $>16 \mathrm{U} / \mathrm{L}$ ). Anaemic patients have a significantly higher level of serum EPO, which increases with the further aggravation of anaemia [19]. The plasma EPO concentration of nonuremic anaemic patients (784 $\mathrm{mIU} / \mathrm{mL}$ ) was also several folds higher than their uremic counterparts [3]. rhuEPO is also used for the treatment of anaemia related to chronic kidney disease. It was found that a subcutaneous (s.c.) injection of 30-45 IU/ kg rhuEPO increased serum EPO levels ranging between 30 and

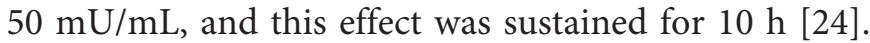
Administration of a high dose (100 IU/kg s.c.) of rhuEPO in healthy volunteers also showed that plasma EPO levels have a $\mathrm{C}_{\max }$ of $10 \mathrm{~h}$ [25]. The serum EPO levels remain above $50 \mathrm{IU} / \mathrm{L}$ after 3 days of administration and return to normal after 1 week. Our study hints at the use of EPO as a growth factor for bacteria.

To gain insight on how such actions of EPO on bacteria are possible, we conducted an in-silico study comprising docking as well as molecular dynamics simulation. Molecular dynamics is performed to analyse the stability of the docked complex. We noted that EPO binds with adhesin (a bacterial cell surface protein) in its small molecule binding site (Fig. 1a) [17]. The interaction of bacterial membrane proteins with EPO was analysed in-vitro by fluorescence spectroscopy. Fluorescence emission intensity measurements were taken at different excitation wavelengths at a fixed $\mathrm{pH}$. It was observed that the intrinsic fluorescence of membrane protein at $\lambda_{\mathrm{Ex} 240} / \lambda_{\mathrm{Em} 484}$ is quenched by EPO in a dose-dependent manner (Fig. 5a). This signifies complex formation. The binding site value was calculated to be more than one indicating that under our experimental condition the bacterial membrane proteins interact with EPO. In vitro fluorescence spectroscopic analysis coupled with molecular dynamics simulation result hints high chance of interaction of human EPO with bacterial adhesion under physiological conditions. Focused experiments involving co-immuno precipitation is expected to generate more direct evidence of the observed phenomenon. It is known that the adhesins interact with host molecules (including soluble macromolecules) for specific functions $[26,27]$, and that host molecules alter bacterial gene expression [28]. Bacterial adhesion (including that of E. coli) is known to play an important role in growth and virulence [29]. We feel that such functions can vary from bacteria to bacteria, subject to the availability of downstream components possibly explaining the different effects of EPO on the growth of $E$. coli and Pseudomonas spp. However, focused studies are required to throw more light in this area. Anecdotal evidence of EPO affecting bacteria is present in the form of differences in gut microbiome of people who reside at high altitudes. Such populace has a high EPO level, which has been implicated as one of the reasons for altered microbiome [30]. However, it is too early to comment more specifically on the issue, and more focused studies must be done in the field.

\section{Statement of Ethics}

The study protocol was approved by the Institute Ethics Committee.

\section{Disclosure Statement}

The authors have no conflicts of interest to disclose.

\section{Funding Sources}

DB acknowledges PGIMER, Chandigarh for providing financial assistance to this study (INT/IEC/2015/235 dated July 15, 2015).

\section{Author Contribution}

All authors participated in the design of the study. A.M. and D.B. conceptualised the study. A.M., A.M., and K.M. conducted the experiments. D.B. supervised the work. S.C., K.M., and R.B. conducted the computational analyses. V.S., A.M., and A.M. collated the data, conducted the analyses and wrote the initial draft. K.M. and D.B. contributed to drafting the manuscript. All authors have read and approved the final manuscript. K.M., D.K., and R.B. conducted the revised experiments. A.M. and D.K. collated the data and conducted the analyses. D.B. and R.B. supervised the revised experiments. K.M. and D.K. wrote the revised manuscript.
References
1 Jelkmann W. Physiology and pharmacology of erythropoietin. Transfus Med Hemother. 2013 Oct;40(5):302-9.
2 Cazzola M. How and when to use erythropoi- etin. Curr Opin Hematol. 1998 Mar;5(2):103- 8.
3 Segal GM, Eschbach JW, Egrie JC, Stueve T, Adamson JW. The anemia of end-stage renal disease: hematopoietic progenitor cell re- sponse. Kidney Int. 1988 May;33(5):983-8. 
4 Grote Beverborg N, Verweij N, Klip IT, van der Wal HH, Voors AA, van Veldhuisen DJ, et al. Erythropoietin in the general population: reference ranges and clinical, biochemical and genetic correlates. PLoS One. 2015 Apr;10(4):e0125215.

5 Tamion F, Le Cam-Duchez V, Menard JF, Girault $\mathrm{C}$, Coquerel A, Bonmarchand G. Serum erythropoietin levels in septic shock. Anaesth Intensive Care. 2005 Oct;33(5):578-84.

6 Corwin HL, Gettinger A, Pearl RG, Fink MP, Levy MM, Shapiro MJ, et al.; EPO Critical Care Trials Group. Efficacy of recombinant human erythropoietin in critically ill patients: a randomized controlled trial. JAMA. 2002 Dec;288(22):2827-35.

7 Meduri GU, Kanangat S, Stefan J, Tolley E, Schaberg D. Cytokines IL-1beta, IL-6, and TNF-alpha enhance in vitro growth of bacteria. Am J Respir Crit Care Med. 1999 Sep; 160(3):961-7.

8 Nairz M, Schroll A, Moschen AR, Sonnweber T, Theurl M, Theurl I, et al. Erythropoietin contrastingly affects bacterial infection and experimental colitis by inhibiting nuclear factor- $\kappa \mathrm{B}$-inducible immune pathways. Immunity. 2011 Jan;34(1):61-74.

9 Huttlin EL, Bruckner RJ, Paulo JA, Cannon JR, Ting L, Baltier K, et al. Architecture of the human interactome defines protein communities and disease networks. Nature. 2017 May;545(7655):505-9.

10 Lyskov S, Gray JJ. The RosettaDock server for local protein-protein docking. Nucleic Acids Res. 2008 Jul;36(Web Server issue):W233-8.

11 Kumar D, Behal S, Bhattacharyya R, Banerjee D. Pseudoesterase activity of albumin: A probable determinant of cholesterol biosynthesis. Med Hypotheses. 2018 Jun;115:42-5.

12 Rajpoot M, Bhattacharyya R, Banerjee D, Sharma A. Melamine binding with arachidonic acid binding sites of albumin is a potential mechanism for melamine-induced inflammation. Biotechnol Appl Biochem. 2017 Jul;64(4):490-5.
13 Habeeb F, Shakir E, Bradbury F, Cameron P, Taravati MR, Drummond AJ, et al. Screening methods used to determine the anti-microbial properties of Aloe vera inner gel. Methods. 2007 Aug;42(4):315-20.

14 Poole RK. The Isolation of Membranes from Bacteria. In: Graham JM, Higgins JA, editors. Biomembrane Protocols: I. Isolation and Analysis. Totowa (NJ): Humana Press; 1993. pp. 109-22.

15 Livnah O, Stura EA, Middleton SA, Johnson DL, Jolliffe LK, Wilson IA. Crystallographic evidence for preformed dimers of erythropoietin receptor before ligand activation. Science. 1999 Feb;283(5404):987-90.

16 Naranda T, Kaufman RI, Li J, Wong K, Boge A, Hallén D, et al. Activation of erythropoietin receptor through a novel extracellular binding site. Endocrinology. 2002 Jun;143(6): 2293-302.

17 Pettigrew DM, Roversi P, Davies SG, Russell AJ, Lea SM. A structural study of the interaction between the Dr haemagglutinin DraE and derivatives of chloramphenicol. Acta Crystallogr D Biol Crystallogr. 2009 Jun;65(Pt 6):513-22.

18 Sargsyan K, Grauffel C, Lim C. How Molecular Size Impacts RMSD Applications in Molecular Dynamics Simulations. J Chem Theory Comput. 2017 Apr;13(4):1518-24.

19 Vogeser M, Schiel X. Serum erythropoietin concentrations in patients with anemia-preliminary hemoglobin-related reference ranges. Clin Lab. 2002;48(11-12):595-8.

20 Nairz M, Sonnweber T, Schroll A, Theurl I, Weiss G. The pleiotropic effects of erythropoietin in infection and inflammation. Microbes Infect. 2012 Mar;14(3):238-46.

21 Chakraborty S, Mittal A, Banerjee D: Human Recombinant Insulin in Supraphysiological Concentration Support Bacterial Growth in Glucose Independent Manner. Int J Drug Dev Res 2016;8:035-040
22 Musher DM, Alexandraki I, Graviss EA, Yanbeiy N, Eid A, Inderias LA, et al. Bacteremic and nonbacteremic pneumococcal pneumonia. A prospective study. Medicine (Baltimore). 2000 Jul;79(4):210-21.

23 Musher DM, Lamm N, Darouiche RO, Young EJ, Hamill RJ, Landon GC. The current spectrum of Staphylococcus aureus infection in a tertiary care hospital. Medicine (Baltimore). 1994 Jul;73(4):186-208.

24 Pavlović-Kentera V, Clemons GK, BiljanovićPaunović L, Marisavljević D, Lezaić V, Pokrajac M, et al. Serum erythropoietin levels in hemodialysed patients after administration of recombinant human erythropoietin. Biomed Pharmacother. 1992;46(1):37-43.

25 Jensen JD, Jensen LW, Madsen JK. The pharmacokinetics of recombinant human erythropoietin after subcutaneous injection at different sites. Eur J Clin Pharmacol. 1994;46(4): 333-7.

26 Pingel LC, Kohlgraf KG, Hansen CJ, Eastman CG, Dietrich DE, Burnell KK, et al. Human beta-defensin 3 binds to hemagglutinin $\mathrm{B}$ (rHagB), a non-fimbrial adhesin from Porphyromonas gingivalis, and attenuates a proinflammatory cytokine response. Immunol Cell Biol. 2008 Nov-Dec;86(8):643-9.

27 Kline KA, Fälker S, Dahlberg S, Normark S, Henriques-Normark B. Bacterial adhesins in host-microbe interactions. Cell Host Microbe. 2009 Jun;5(6):580-92.

28 Moorthy S, Keklak J, Klein EA. Perspective: Adhesion Mediated Signal Transduction in Bacterial Pathogens. Pathogens. 2016 Feb; 5(1):E23.

29 Stones DH, Krachler AM. Against the tide: the role of bacterial adhesion in host colonization. Biochem Soc Trans. 2016 Dec;44(6): 1571-80.

30 Li K, Dan Z, Gesang L, Wang H, Zhou Y, Du $\mathrm{Y}$, et al. Comparative Analysis of Gut Microbiota of Native Tibetan and Han Populations Living at Different Altitudes. PLoS One. 2016 May;11(5):e0155863. 